\title{
Effective Marketing Channels of Paddy in Keerapalayam Block in Cuddalore District, Tamil Nadu
}

\author{
C. Ramesh \\ Assistant Professor, Department of Economics, \\ Government Arts Collage for Women (Autonomous), Kumbakonam, Tamil Nadu, India \\ E-Mail: c_ramesh45@yahoo.com
}

\begin{abstract}
Agricultural marketing plays a vital role in agricultural development which is a pre-requisite for development in other sectors and for the overall development of the economy. The agricultural marketing is defined as the operations involved in the movement of food and raw materials from the farmers to the final consumer and the effect of such operations on producers and middlemen (Singh 1984). In India, there exists an elaborate and inter-connected system of agricultural produce markets through which the produce flows from the producer to the consumer. The market system in India comprises 30,000 rural primary markets, 7,000 wholesale assembling markets at the secondary stage and terminal distribution markets in every urban city or town (Ramaswamy 1995). An efficient marketing is a sine qua non in the economy of all countries, in general and of agricultural countries, in particular. It definitely exerts a powerful influence on country's production and consumption pattern; it plays a prominent role in regulating supply and demand; and it helps in the elimination of duplication of services and wastages of valuable resources. The present study is confined to the study of marketing system of food crops namely paddy in Cuddalore District. Hence, the present chapter makes an attempt to study the marketing system in terms of storage, marketing channels and the like. Further, an attempt has been made to anlayse marketing cost, marketing margin, pricespread and marketing efficiency. For better exposition, the present study is organised under the following headings: Marketable surplus of paddy; Storage, cost of storage and Net gains earned by storage; Market Structure; Marketing cost, Marketing margin and Price-spread; Marketing Efficiency and Marketing problems

Keywords: Marketing, Agriculture, Rural, Development
\end{abstract}

\section{INTRODUCTION}

Agricultural marketing plays a vital role in agricultural development which is a pre-requisite for development in other sectors and for the overall development of the economy. The agricultural marketing is defined as the operations involved in the movement of food and raw materials from the farmers to the final consumer and the effect of such operations on producers and middlemen. In India, there exists an elaborate and inter-connected system of agricultural produce markets through which the produce flows from the producer to the consumer. The market system in India comprises 30,000 rural primary markets, 7,000 wholesale assembling markets at the secondary stage and terminal distribution markets in every urban city or town. An efficient marketing is a sine qua non in the economy of all countries, in general and of agricultural countries, in particular. It definitely exerts a powerful influence on country's production and consumption pattern; it plays a prominent role in regulating supply and demand; and it helps in the elimination of duplication of services and wastages of valuable resources. Marketing perhaps has its greatest and most enduring role to play in the economic changes in developing countries. An efficient internal marketing system for agricultural commodities holds the key for rural development and for meeting the challenges thrown up by explosive growth of population in developing countries. Marketing holds the key for agricultural development which could determine the quality of urban life.

There is a great impact of Green Revolution on the power structure at various levels and the issue of taxation of agricultural incomes. In the year 1966, the implementation of technological change in High Yielding Varieties Programme (HYVP) in all districts selected under Intensive Agricultural District Programme (IADP) scheme was introduced. The strategy was concerned with higher productivity of crops but with multiple cropping, the HYVP had assumed 'crucial importance' in the Planning Commission's agricultural development strategy. The most interesting feature of the new agricultural strategy was that the movement for scientific agriculture and programmes for research and extension received fresh stimulus. A three dimensional approach towards agricultural development was chemical technology that guaranteed minimum paddy as an incentive to agricultural production. Technological change or the new strategy proposes to make a new technological breakthrough in India which comprises the introduction of new and HYV of improved seeds, increased application of the recommended dose of fertilizers and extension of the use of pesticides that can save crop from destruction by insects. This technological change brought spectacular changes in the agriculture production of our country. The increase in production of food grains recorded after 1966-67 is described as Green Revolution. The rapid introduction of HYV of paddy and wheat and their multiplied effects on other crops justify the name Green Revolution.

The new agricultural strategy technology adopted since the mid sixties has helped in revolutionizing Indian agriculture. Technological change in agriculture is characterised by the use of pesticides, irrigation, machinery, improved 
implements, soil conservation and the like. The successful adoption of these components of new strategy has resulted in the increase of agricultural production. The introduction of above mentioned components of new agriculture strategy depends upon factors like irrigation, size of farm, capital, institutional credit, and extension services. There are many regions with better factor endowments. The new agricultural strategy was the first to adopt modern inputs and derive the benefits as a sequel. Since India's independence great strides have been made in the field of agriculture. Efforts made under the Five Year Plans resulted in the growth rate of agricultural output by about 2.7 per cent per annum as compared with 0.8 per cent per annum during the first half of the $20^{\text {th }}$ century. The Green Revolution of the 1960's initiated a gradual transformation of the traditional household agriculture into modern and scientific agriculture in several parts of India. The introduction of new technology in agriculture brought about unprecedented increases in yield and output of major cereal crops like rice and wheat. Of the several food grains produced by the agricultural sector, rice/paddy, occupies a significant place as it is the staple food of about 2.4 billion people and provides more than 20 per cent of their calorie intake. The present study is confined to the study of marketing system of food crops namely paddy in Cuddalore District. Hence, the present chapter makes an attempt to study the marketing system in terms of storage, marketing channels and the like. Further, an attempt has been made to anlayse marketing cost, marketing margin, price-spread and marketing efficiency. For better exposition, the present study is organised under the following headings: Marketable surplus of paddy; Storage, cost of storage and Net gains earned by storage; Market Structure; Marketing cost, Marketing margin and Price-spread; Marketing Efficiency and Marketing problems.

\section{REVIEW OF LITERATURE}

Baradhan (2013) formulated a function for marketed surplus and found that the response of marketed surplus of paddy to its price was negative while that of output supply to price was positive. The input prices had positive effect on marketed surplus whereas they had negative effect on output supply.

Ram and Swarup (2015) observed that the marketing costs, margins and transportation costs were high because of the bulkiness of agricultural products studied by them. A comparison between regulated and non-regulated markets showed no marked improvement in marketing efficiency between the two.

Ramamoorthy and Srinivasan (2015) while analysing the problems of production and marketing of tomatoes in Coimbatore taluk observed that in the wholesale market, tomato was sold on volume basis in bamboo baskets and the retailers sold tomato on weight basis. The farmers were not aware of the ruling price for tomato in the retail markets which led to a low share of consumers' rupee to the farmers.
Bhatia and Ram (2014) studied the marketing efficiency in retail vegetable markets in Delhi through marketing costs and margins, consumer prices, availability of physical marketing facilities and market competitions. They found that the retailer's margins accounted for about 50 per cent of the consumer's price and the consumers were to pay high prices due to the perishability and bulkiness of the product. Among the different classes of retailers, pavement sellers got the lowest average percentage of net retail margins.

Kahage and Suryawanshi (2001) observed that the producer's share in the consumer's price was 47.73 per cent while 43 per cent of the total cost was the commission and profits of traders. The share of the different intermediaries in consumer's rupee worked out to $19.01,16.12$ and 8.47 per cent for wholesaler, retailer and commission agent respectively in the marketing of roses.

Pandey et al., (2004) observed that the net price received by the farmers had a negative and significant relationship between distance and marketing cost, but a positive and significant relationship with marketed surplus. They concluded that the producers exercised their preference to sell their agricultural produce to the commission agents according to family tradition. Immediate need for money after harvest and lack of storage facilities also led to such sales.

Shide et al., (2004) while analysing the structural changes in the arecanut assembling market concluded that changes in buyer and seller concentrations had opposite effects on the price of arecanut. Increase in buyer concentration increased the market price, while increase (decrease) in seller concentration decreased (increased) the market price.

Patil et al., (2001) analysed the marketing costs and pricespared for mangoes in four marketing channels. Among the four channels, direct sale from producer to consumer was found to be the most profitable and the one through preharvest contractor was the least profitable.

Sundaresan and Thanasekaran (2005) in their study on production and marketing of grapes identified severity of diseases and pest attack, lack of adequate capital facilities to meet the initial establishment costs and high cost of inputs as major production problems, while unorganised market structure, high marketing costs and unnecessary deductions and lack of finance facilities ranks as the important marketing problems.

Mohandoss (2004) while evaluating the horticultural produce movements to and from Bangalore market found that the transport cost was a function of weight, distance moved and the mode of transportation. He concluded that for relatively short distance movement, trucks could be used, while for long distance transportation a combination of rail and trucks would be more beneficial. 
Patil et al., (2004) observed that the Channel I (direct sale to consumers) and Channel II (sale through co-operatives) were the most efficient channels of mango trade. In these channels each marketing function was also found to be most efficient as compared to corresponding market functions performed in Channel III (sales through commission agents) and Channel IV (sale through pre-harvest contractors).

Nawadkar et al., (2001) observed that the cost of marketing of onion was Rs.33.00 and Rs.26.1 per quintal at Bombay and Pune markets respectively. The important items of marketing cost were transportation, commission and packing material. The producer's share in consumer's rupee was 72.68 and 53.12 per cent at Bombay and Pune respectively. The relationship between monthly arrivals and wholesale price of onion was negative and significant at 1 per cent level.

Agarwal and Sharma (2012) opined that the marketing cost of red chillies as per cent of consumer's price was higher when chillies were marketed as wet compared to semi-dried and dried farms because of higher transport costs for wet and semi-dired ones. The marketing margins were 35.48, 33.11 and 35.76 per cent in wet, dried and semi-dried chillies respectively. Warde et al., (2015) observed that the rotting losses of stored onion after 120 and 240 days had shown a significant difference. The total loss of onion bulbs after 90 and 150 days was found to be significant while after 30, 60 and 120 days, it was non-significant.

Naik et al., (2013) concluded that the cost of marketing incurred by farmers varied not only between different size group of farmers, but also between different channels through which the sales were effected. The transportation charge itself contributed to nearly 50 per cent of the total cost due to location of market at a distant place followed by package cost. Sixty five per cent of the farmers disposed of 82.83 per cent of their produce through village traders because of their poor bargaining capacity and debt commitments with village traders.

\section{OBJECTIVES}

1. To analyse the existing marketing channels for paddy and to evaluate the marketing cost, marketing margin, price spread and marketing efficiency of different channels.

2. To find out the determinants of net return and marketable surplus for the sample farmers.

\section{METHODOLOGY}

\section{A. Selection of the Study Area}

The area chosen for the present study is Cuddalore district, situated at the southern part of Tamil Nadu. Eighty- three per cent of its population is residing in villages and 58.8 per cent of its working population is anchored in agriculture and its allied activities. The area under paddy was 19638 hectares in 2015-16, which clearly indicates the importance of the paddy in the area. As the soil is fertile, more than two crops are raised. Cuddalore, the District headquarters, has a major paddy market. There are many paddy mills in and around Cuddalore. Hence, the choice of Cuddalore district as the unit of the present study.

\section{B. Sampling Design}

Multistage stratified random sampling technique was applied in the present study. A sample of 300 farmers will be collected from four different categorize namely Marginal Farmers (75), Small Farmers (75), Medium Farmers (75), and Large Farmers (75). This study concentrates on two Blocks only viz, Kuringipadi and Bhuvanagirii Simalerly Kuringipadi and Chidambaram Taluks are two among 6 taluks in the Cuddalore district. There are 150 samples to be collected in each block (viz) Kuringipadi and Bhuvanagiri.There are three villages are selected from each block for the present study. The selected villages are Karunkuzhi, Maruvai and Nainarkuppam under Kuringipadi block and Karaimedu ,Maruthur and Kolakkudi under Bhuvanagiri block. Therefore each block consists of 150 samples in the present study area.

\section{Collection of Data}

A reconnaissance survey of the study area was undertaken to form a crystal clear picture of the process and activities involved in paddy cultivation under actual farming conditions. Based on the information gathered at a farm level, a detailed schedule was drafted, pre-tested and used in the field-survey. The objectives of the study were clearly explained to the farmers personally and their co-operation ensured. The details regarding the general characteristics of the sample farmers, farm structure, size of holding, cropping pattern, cost and returns, methods of sale, quantity retained, quantity sold and other aspects relating to the overall objectives of the study were collected from the sample farmers through the direct personal interview method. Even though the farmers did not maintain adequate farm records and accounts, they were able to furnish the particulars on the strength of their long association with farming. However, to minimize recall bias, suitable cross checks and re-checks were carried out.

\section{Sources of Data}

\section{Primary Data}

Three separate interview schedules were prepared to collect the required information from the market intermediaries namely the village traders, commission agents and wholesalers/retailers of paddy. One interview schedule was framed for village traders with a view to collect data related to the price paid and received by them and costs incurred by them in paddy marketing. Second interview schedule was prepared and used for commission agents, so as to gather 
information relating to price paid and received and cost incurred in the marketing of paddy. Third interview schedule was prepared for wholesalers or retailers in order to collect cost incurred by them and price paid and received by them in the process of marketing. Particulars regarding the method of purchase, cost of marketing, expenditure incurred on establishment charges, commission, prices paid and received and the like were collected

\section{Secondary Data}

Secondary data were collected from the Directorate of Economics and Statistics, Government of Tamil Nadu, Chennai, Office of Assistant Director of Economics and Statistics, Cuddalore District, Office of the Cuddalore District Market Committee, Cuddalore and Office of the Joint Director of Agriculture, Cuddalore. Besides books, journals and magazines were consulted. Journals such as Indian Journal of Agricultural Marketing, Indian Journal of Agricultural Economics, Agricultural Marketing, Indian Journal of Marketing and other relevant journals were referred to for collecting secondary data for the study.

\section{Period of Study}

The field survey was conducted from September 2009 to March 2010 for the collection of primary data. This period relates to the main season for paddy cultivation in Cuddalore district. The reference period of the survey is 2009-10.

\section{RESULTS AND DISCUSSION}

\section{A. Marketing Channels}

The marketing channel is the route taken by the title to the goods as they move from producer to ultimate consumer.
Marketing channels are combinations of agencies through which the seller who is often, though not necessarily manufacturer, markets his product to the ultimate consumer. Parashwar has defined market channel as the vehicle of marketing system, the unit within which all marketing activity takes place.

Bilgrani has defined market channel as a distributory that is involved in direct and indirect transfer of title to a product as it moved from producers to consumers or industrial users. In the present study, marketing channel refers to the collection of agencies and movements associated with the exchange of paddy from the primary producer to the ultimate consumer.

The paddy in Cuddalore district is sold through middlemen namely commission agents, village traders, wholesalers and retailers. The marketing channels identified are,

1. Channel $\mathrm{I}=$ Producer - Village Traders - Miller Consumer

2. Channel II = Producer - Regulated market - Consumer

3. Channel III = Producer- Commission Agent Retailer/Miller - Consumer.

The farmers in the study area have chosen only the commission agents in most cases as the main intermediary. Eighty per cent of the total produce is passed through the commission agents and wholesalers cum retailers.

\section{B. Choice of the Middlemen}

It is not only the number of days stored but also the agent or the merchant middlemen through or to whom the produce sold influences the net price realised by the farmers. Table 6.9 shows the different types of middlemen through whom the sample farmers are selling their paddy.

TABLE I MidDlemen CHOSEN By THE SAMPLE FARMERS

\begin{tabular}{|c|c|c|c|c|c|c|}
\hline S. No. & Middlemen & $\begin{array}{l}\text { Marginal } \\
\text { Farmers }\end{array}$ & Small Farmers & $\begin{array}{l}\text { Medium } \\
\text { Farmers }\end{array}$ & Large Farmers & Total \\
\hline 1. & Village Traders & $\begin{array}{c}8 \\
(10.67)\end{array}$ & $\begin{array}{c}5 \\
(6.67)\end{array}$ & $\begin{array}{c}7 \\
(9.33)\end{array}$ & $\begin{array}{c}9 \\
(12.00)\end{array}$ & $\begin{array}{c}29 \\
(9.67)\end{array}$ \\
\hline 2. & Regulated Market & $\begin{array}{c}17 \\
(22.67)\end{array}$ & $\begin{array}{c}12 \\
(16.00)\end{array}$ & $\begin{array}{c}15 \\
(20.00)\end{array}$ & $\begin{array}{c}19 \\
(25.33)\end{array}$ & $\begin{array}{c}63 \\
(21.00)\end{array}$ \\
\hline \multirow[t]{2}{*}{3.} & Commission Agents & $\begin{array}{c}50 \\
(66.66) \\
\end{array}$ & $\begin{array}{c}58 \\
(77.33) \\
\end{array}$ & $\begin{array}{c}53 \\
(70.67) \\
\end{array}$ & $\begin{array}{c}47 \\
(62.67) \\
\end{array}$ & $\begin{array}{c}208 \\
(69.33) \\
\end{array}$ \\
\hline & Total & $\begin{array}{c}75 \\
(100)\end{array}$ & $\begin{array}{c}75 \\
(100)\end{array}$ & $\begin{array}{c}75 \\
(100)\end{array}$ & $\begin{array}{c}75 \\
(100)\end{array}$ & $\begin{array}{c}300 \\
(100)\end{array}$ \\
\hline
\end{tabular}

Source: Primary data Note: Figures in parentheses are the percentages of the total

It is observed from Table I that 69.33 per cent of farmers sold their produce through the commission agents in the study area. The remaining 21.00 and 9.67 per cent sold their produce through regulated markets and village traders respectively.

The commission agents are the most preferred middlemen by the marginal, small, medium and large farmers because of the facilities offered by them.

\section{Sale to Village Traders}

The number of farmers selling and the quantity of paddy sold through village traders are analysed and presented in Table II.

It is seen from Table II that in total, 29 farmers are selling their paddy through the village traders. Out of 29 farmers, 8 are marginal farmers, 5 are small farmers, 7 are medium 
farmers and the remaining 9 are large farmers. It is concluded that out of 29 farmers, the most of the large farmers sold their produce through Village traders which constitute 31.03 per cent whereas the quantity of paddy was meager which constitute 1.62 quintals per acre. But the small farmers sold their produce through village traders in large quantity which constitute 3.82 quintals per acre.

TABLE II NUMBER OF FARMERS AND QUANTITY OF PADDY SOLD THROUGH VILLAGE TRADERS

(Quintals per acre)

\begin{tabular}{|c|l|c|c|c|}
\hline $\begin{array}{c}\text { S. } \\
\text { No. }\end{array}$ & $\begin{array}{c}\text { Size of } \\
\text { Farmers }\end{array}$ & $\begin{array}{c}\text { Number } \\
\text { of } \\
\text { Farmers }\end{array}$ & $\begin{array}{c}\text { Percentage of } \\
\text { Farmers sold } \\
\text { through Village } \\
\text { Traders }\end{array}$ & $\begin{array}{c}\text { Average Quantity } \\
\text { of Paddy sold (in } \\
\text { quintals per acre) }\end{array}$ \\
\hline 1. & Marginal & 8 & 27.59 & 2.89 \\
\hline 2. & Small & 5 & 17.24 & 3.82 \\
\hline 3 & Medium & 7 & 24.14 & 2.44 \\
\hline 4. & Large & 9 & 31.03 & 1.62 \\
\hline & Overall & 29 & 100.00 & 10.77 \\
\hline
\end{tabular}

Source: Primary data Note: Figures in parentheses are the percentages of the total

In order to rank the reasons for selling paddy through various middlemen like village traders, commission agents and wholesalers and retailers, the Garrett's Ranking Technique was adopted.

The respondents were given the reasons and asked to rank them according to their choice. The order of merit given by the respondents was converted into ranks by using the formula:

$$
\begin{aligned}
& 100\left(\mathrm{R}_{\mathrm{ij}}-0.50\right)
\end{aligned}
$$

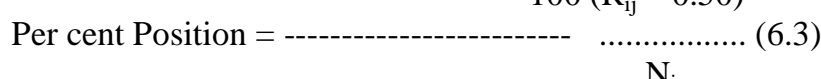

Where,

$$
\begin{aligned}
& R_{i j}=\text { Rank given for }\left(i^{\text {th }} \text { factor by } j^{\text {th }}\right. \text { farmer) } \\
& N_{i}=\text { Number of constraints ranked by } j^{\text {th }}
\end{aligned}
$$

households.

The per cent position of each rank thus obtained was converted into scores using the table given by Garrett. The scores of individuals representing each reason were added together and divided by the total number of farmers for whom the scores were added. The mean scores for all the reasons were analysed in the ascending order, ranks assigned and the important factors identified.

TAble III Reasons For Selling Rice Through Village Traders

\begin{tabular}{|c|l|c|c|}
\hline S. No. & \multicolumn{1}{|c|}{ Reasons } & Score & Rank \\
\hline 1. & No storage cost & 64.31 & IV \\
\hline 2. & Easy method of sale & 51.26 & V \\
\hline 3. & No price difference & 70.12 & II \\
\hline 4. & Long-term practice & 43.68 & VI \\
\hline 5. & No transport cost & 72.63 & I \\
\hline 6. & No commission charges & 66.91 & III \\
\hline 7. & Immediate payment & 30.16 & VII \\
\hline
\end{tabular}

Source: Primary data
The reasons for selling the paddy through village traders are analysed and presented in Table III.

Table III shows that among the reasons to sell the paddy through village traders, no transport cost ranks first followed by no price difference, no commission charges, no storage cost, easy method of sale, long term practice and immediate payment.

\section{Regulated Markets}

The direct channel which has lesser number of middlemen is the wholesaler/retailer. But this channel is not very popular among the farmers because of various reasons. The number of farmers and quantity of paddy sold to the regulated markets are analysed and presented in Table IV.

TABLE IV NuMBERS OF FARMERS AND QUANTITY OF PADDY SOLD THROUGH REGULATED MARKETS

\begin{tabular}{|c|l|l|c|c|}
\hline \multicolumn{1}{|c|}{} & \multicolumn{1}{|c|}{ (Quintals per acre) } \\
$\begin{array}{c}\text { No. } \\
\text { Size of } \\
\text { Farmers }\end{array}$ & $\begin{array}{c}\text { Number } \\
\text { of } \\
\text { Farmers } \\
\text { of Farmers } \\
\text { sold } \\
\text { through } \\
\text { Regulated } \\
\text { Markets }\end{array}$ & $\begin{array}{c}\text { Average } \\
\text { Quantity } \\
\text { of Paddy } \\
\text { sold (in } \\
\text { quintals } \\
\text { per acre) }\end{array}$ \\
\hline 1. & Marginal & 17 & 26.98 & 4.29 \\
\hline 2 & Small & 12 & 19.05 & 6.22 \\
\hline 3 & Medium & 15 & 23.81 & 5.31 \\
\hline 4. & Large & 19 & 30.16 & 2.38 \\
\hline & Overall & 63 & 100.00 & 18.20 \\
\hline
\end{tabular}

Source: Primary data Note: Figures in parentheses are the percentages of the total

It is observed from Table IV that 30.16 per cent of large farmers sold their produce through regulated markets and it was followed by marginal, medium and small farmers which constitute 26.98 per cent, 23.81 per cent and 19.05 per cent respectively. The average quantity of paddy sold per acre by marginal, small, medium and large farmers is $4.29,6.22,5.31$ and 2.38 quintals respectively.

The reasons for selling paddy through regulated markets are ranked and presented in Table $\mathrm{V}$.

Table V Reasons For Selling Rice Through Regulated Markets

\begin{tabular}{|c|l|c|c|}
\hline S. No. & \multicolumn{1}{|c|}{ Reasons } & Score & Rank \\
\hline 1. & No storage cost & 78.96 & I \\
\hline 2. & Easy method of sale & 70.12 & III \\
\hline 3. & Long term practice & 65.16 & IV \\
\hline 4. & No commission charge & 74.18 & II \\
\hline 5. & Credit facilities & 30.63 & VII \\
\hline 6. & Better price & 56.91 & VI \\
\hline 7. & More off-take & 61.48 & V \\
\hline
\end{tabular}


Table V shows that among the reasons, no storage cost ranks first the reasons namely, no commission charges, easy method of sale and long term practice are ranked II, III and IV whereas the Vth, VIth and VII ranks are assigned to reasons namely more off-take, better price and credit facilities respectively.

\section{E. Sale to Commission Agent}

The most popular and dominant channel in the district is the commission agent. The commission agent advances loans with or without interest to the farmers whenever they need it. The commission agent recovers the entire amount from the farmers at the time of sale. The number of farmers and quantity of paddy sold through commission agent are discussed and presented in Table VI.

TABle Vi Number Of FARMERS AND QuANTITy OF PADDY Sold THROUGH COMMISSION AGENT

\begin{tabular}{|c|l|c|c|c|}
\hline $\begin{array}{c}\text { S. } \\
\text { No. }\end{array}$ & $\begin{array}{c}\text { Size of } \\
\text { Farmers }\end{array}$ & $\begin{array}{c}\text { Number } \\
\text { of } \\
\text { Farmers }\end{array}$ & $\begin{array}{c}\text { Percentage of } \\
\text { Farmers sold } \\
\text { through } \\
\text { Regulated } \\
\text { Markets }\end{array}$ & $\begin{array}{c}\text { Average } \\
\text { Quantity of } \\
\text { Rice sold (in } \\
\text { quintals per } \\
\text { acre) }\end{array}$ \\
\hline 1. & Marginal & 50 & 24.04 & 7.90 \\
\hline 2. & Small & 58 & 27.88 & 9.95 \\
\hline 3. & Medium & 53 & 25.48 & 10.24 \\
\hline 4. & Large & 47 & 22.60 & 13.92 \\
\hline & Overall & 208 & 100.00 & 42.01 \\
\hline
\end{tabular}

Source: Primary data Note: Figures in parentheses are the percentages of the total

It is found from Table VI that out of 208 farmers, 27.88 per cent of the small farmers selected commission agent to sell their produce and it is followed by medium farmers, marginal farmers and large farmers which constitute 25.48 per cent, 24.04 per cent and 22.60 per cent respectively. The average quantity sold per acre varied from 7.90 quintals to 13.92 quintals with respect to marginal and large farmers.

The reasons for the choice of commission agents are presented in Table VII.

Table Vit Reasons For Selling Rice Through Commission Agent

\begin{tabular}{|c|l|c|c|}
\hline S. No. & \multicolumn{1}{|c|}{ Reasons } & Score & Rank \\
\hline 1. & Availability of credit facilities & 78.16 & I \\
\hline 2. & Better price & 50.12 & III \\
\hline 3. & Immediate cash after sale & 68.96 & II \\
\hline 4. & Long term practice & 35.14 & V \\
\hline 5. & Higher off-take & 40.10 & IV \\
\hline \multicolumn{3}{|c|}{ Source: Primary data }
\end{tabular}

Most of the farmers prefer the commission agents as their intermediary because the commission agents provide credit facilities to the farmers whenever they need. Therefore it is ranked first. Other reasons namely immediate cash after sale, better price, high off-take and long term practice are ranked II, III, IV and V.

\section{MAJOR FINDINGS}

The study on market structure, marketing efficiency and price-spread revealed that the intermediaries played a vital role in paddy marketing in Cuddalore district. The retention of paddy accounted for 9.23 per cent, 8.87 per cent, 9.48 per cent and 10.05 per cent in the marginal, small, medium and large farmers category. About 79 per cent of the retention was found to be for domestic uses. Marketable surplus of paddy was found to be nearly 79 per cent of the total production. The results of fitted regression equation to identify the determinants of marketable surplus revealed that marketable surplus of paddy increased by 74.68 quintals for every one acre increase in area under paddy. Similarly for every one rupee increase in the price of paddy per quintal it increases by 0.79 quintals.

It is observed from the analysis that the percentage of quantity stored to the marketable surplus of paddy was 27.95 per cent, 32.52 per cent, 30.74 per cent and 38.88 per cent for marginal, small, medium and large farmers respectively. The mean storage loss was 16.40 per cent, 13.11 per cent, 13.46 per cent and 14.04 per cent for marginal, small, medium and large farms respectively. It constituted 4.69 per cent, 4.26 per cent, 4.14 per cent and 5.45 per cent of the marketable surplus in marginal, small, medium and large farms respectively. The percentage of marketed surplus to marketable surplus was found to be 95.31 per cent, 95.74 per cent, 95.86 per cent and 94.54 per cent for marginal, small, medium and large farms respectively. The channel through which the paddy was marketed was identified as three in Cuddalore district. More than 69.33 per cent of the producers preferred to sell through commission agents. The availability of credit facilities from commission agents and absence of storage cost were found to be the major reasons influencing the selection of middlemen for the sale of paddy in Cuddalore district.

Channel I, net price received was lower due to the higher marketing cost. The results of marketing efficiency computed by the Shepherd's formula, Acharya and Agarwal's formula and Composite Index method showed that Channel III, Producer - Wholesaler - Retailer Consumer was the most efficient channel in paddy marketing. The Garrett's ranking technique was adopted to identify the major problems in the marketing of paddy. It was found that the fluctuations in prices stood first in the ranking followed by heavy commission charges and lack of finance.

\section{CONCLUSION}

Thus, it is concluded from the analysis that medium farmers are economically more efficient than the other farmers category irrespective of varieties of paddy cultivation in the 
study area. This could be due to the better supervision and more efficient farm management favoured by the smaller size of operational holdings. This indicated that apart from efficient allocation of inputs, direct supervision and farm management are crucial determinants of economic efficiency. The results of marketing efficiency computed by the Shepherd's formula, Acharya and Agarwal's formula and Composite Index method showed that Channel III, Producer - Wholesaler - Retailer - Consumer was the most efficient channel in paddy marketing. The Garrett's ranking technique was adopted to identify the major problems in the marketing of paddy. It was found that the fluctuations in prices stood first in the ranking followed by heavy commission charges and lack of finance.

\section{REFERENCES}

[1] Naik, A. D., Shankara Murthy, H. G. \& Kachapur. (2014). Marketing of Onions in Bijpur District, Karnataka - An Economic Analysis. The Bihar Journal of Agricultural Marketing, 3(3),

[2] Gupta, A. P. (1975). Marketing of Agricultural Produce in India, Vora and Company Publications Pvt. Ltd., 1 ,

[3] Agarwal, N.L. and Sharma, S.C. (2008, August).Marketing of Red Chillies in Rajasthan. Spice India, August (2012).

[4] Ansari, A.A. and Ismail, S.A. Paddy Cultivation In Sodic Soil Through Vermitech. International Journal of Sustainable Crop Production, 3(5).

[5] Basavaraja, H., Mahajanashetti, S. B. \& Sivanagaraju, P. (2008, OctDec). Technological Change in Paddy Production: A Comparative Analysis of Traditional and SRI Methods of Cultivation. Indian Journal of Agricultural Economics, Research Notes, 63(4).

[6] Bhogal, T. \& Arora, V. P. S. (1996). Marketable and Marketed Surplus of Milk in North-West Uttar Pradesh. The Bihar Journal of Agricultural Marketing, 4(2).

[7] Nawadkar, D. S., Mahandule, D. K., Sale, P. L. \& Dangat, S. B. (2001). Marketing of Vegetables in Western Maharashtra. Indian Journal of Agricultural Marketing, 5(2), 178-184.

[8] FAO. (1976). Report on FAO/RED Workshop on the Effective Use of Marketing for the Development of Small Farms in Asia. Held in Thailand, 5 .

[9] Bhatia, G. R. \& Ram, G. S. (2014). Marketing Efficiency in Retail Vegetables Markets in Delhi. Agricultural Marketing, 20, 13-17.

[10] Bhalla, G. S. \& Gurmall Singh, (2001). Indian Agriculture, Sage Publications, New Delhi, (Book Review by V.S.Gupta), Kurushetra, 50(6), 46

[11] Ram, G. S. and Swarup, B. (2015). Marketing Costs, Margins and Efficiency in a Regulated Fodder Market - A Case Study. Agricultural Marketing, 17(2), 12-17.

[12] Patil, H. N., Kumar, P. \& Muralidharan, M. A. (2001). Efficiency of Marketing of Mangoes in Ratnagiri District (Maharashtra). Indian Journal of Marketing, 14(7), 15-17.

[13] Patil, H. N., Kumar, P. \& Muralidharan, M. A. (1983). Marketing Margins and Price-Spread in the Marketing of Alphonso Mangoes in Ratnagiri District. Indian Journal of Marketing, 14(4), 21-24.

[14] Harish Nayyar and Ramasamy, P. (1995). (Ed.), Globalization and Agricultural Marketing, Rawat Publications, New Delhi, 28.
[15] Baradhan, K. (2013). Price and Output Response of Marketed Surplus of Foodgrains - A Cross Sectional Study of Some North Indian Villages. American Journal of Agricultural Economics, 52(1), 50-61.

[16] Ramamoorthy, K. \& Srinivasan, N. (2015). An Economic Enquiry into the Problems of Productions and Marketing of Tomato in Coimbatore Taluk, Department of Agricultural Economics, Tamil Nadu Agricultural University, Coimbatore, 45.

[17] Kumar, L. R., Srinivas, K. \& Singh, S. R. K. (2005, July-Sept). Technical Efficiency of Rice Farms under Irrigated Conditions of North West Himalayan Region - A Non-Parametric Approach. Indian Journal of Agricultural Economics, 60(3).

[18] Lallan Singh. (1984). Relationship between Apex and Primary Cooperative Marketing in Bihar. The Co-operator, 22(9), 245.

[19] Kahage, M. \& Suryawanshi, S. D. (2001). Production and Marketing of Roses in Western Maharashtra. Indian Journal of Marketing, 10(4).

[20] Agarwal, N. L. \& Sharma, S. C. (2012, August). Marketing of Red Chillies in Rajasthan. Spice India, 16-21.

[21] Naik, A. D., Shankara Murthy, H.G. \& Kachapur. (2014). Marketing of Onions in Bijpur District, Karnataka - An Economic Analysis. The Bihar Journal of Agricultural Marketing, 3(3).

[22] Sundaresan, R. \& Thanasekaran, M. (2005). Production and Marketing of Grapes in Madurai District. Indian Journal of Marketing, 14(8), 26-27.

[23] Raha, S. K. \& Beten, M. A. (2012). Vegetables Marketing in Bangladesh: Do Consumers Pay Higher Price?. Economic Affairs, $40(1)$

[24] Ramesh, D. \& Ramasamy, K. (2004, August). India's Rice Production and Exports. Kisan World, 31(8).

[25] Rasid, Y. D. \& Srivastava, G. C. (2001). An Economic Analysis of Marketing of Ginger in Samastipur (Bihar) and Possibilities of its Export. Indian Journal of Agricultural Marketing, Conference Special.

[26] Reddy, G. P. \& Chengappa, P. G. (2015). Factors Affecting Marketed Surplus of Paddy. Indian Journal of Agricultural Marketing, 5(2).

[27] Warde, S. D., Desale, S. B. \& Shinde, K. G. (2015). Storage Behaviour of Onion Cultivators in Rangda (Late Rainy) Season. Vegetable Science, 22(2), 120-121.

[28] Sadhu \& Mahajan, (1985). Technological Change and Agricultural Development in India, Himalaya Publishing House, New Delhi, 10.

[29] Shashanka Bhide, Ashok Chowdhury, Earl O'Heady \& Muralidharan, M. A. (1981). Structural Changes in an Agricultural Assembling Market (Arecanut). Indian Journal of Agricultural Economics, 36(2), 25-34,

[30] Suresh, A. \& Keshava Reddy, T. R. (2006, Jan-June).Resource-use efficiency of Paddy Cultivation in Peechi Command Area of Thrissur District of Kerala: An Economic Analysis. Agricultural Economics Research Review, 19.

[31] Mohandoss, V. (2004). Spatial Flow Patterns and Rail-Truck Transportation of Horticultural Produce for Bangalore Market. Indian Journal of Agricultural Economics, 39(2), pp.239-50.

[32] Pandey, V. K., Gupta D. D. \& Himmat Singh. (2004). A Case Study on Price-Spread of Agricultural Commodities in Kurukshetra District (Haryana). Indian Journal of Agricultural Economics, 34(4), 210.

[33] Vargheese, K. P., Sharma, P. M. and Gupta, S. S. (2015). Infrastructural, Development of Regulated Markets for Agriculture in Rajasthan. Journal of Agricultural Marketing, (Conf. Spl.), 12(3). 